\title{
STRUKTUR DAN KINERJA INDUSTRI KERTAS DAN PULP DI INDONESIA: SEBELUM DAN PASCAKRISIS
}

\author{
Fitri Wulandari \\ Sekolah Tinggi Agama Islam Negeri (STAIN) Surakarta \\ E-mail: qimpron@yahoo.com
}

\begin{abstract}
This research is intended to describe how concentrate of industrial market of pulp and paper before and after crisis was occur, and to analyze how impact of structure to pulp and paper industrial performances before and after crisis. Method being used in this research is concentration ratio $(C R)$ either $C R_{4}$ or $C R_{8}$. This research is also uses multiple regression to see impact of independent variables (market share, cost of capital, efficiency and cost of raw material) to dependent variable (added value). The results of research are concentration ratio $(C R)$ of total raw material, $C R$ of added value, and CR of output; all of those are increase both $C R_{4}$ and $C R_{8}$. This means that crisis have had impact toward increasing concentration ratio pulp and paper industries, whereas $C R$ of wage is decrease. $C R_{4}$ decrease by $13 \%$ and $C R_{8}$ decrease by $14 \%$. The results of this research also indicate that cost of capital have negative impact to added value of company. Companies whose have less capital would have higher profit, vice versa. Cost of raw material has negative impact on company's profit. Market share has positive impact on company's profit.
\end{abstract}

Keywords: concentration ratio, industrial market, pulp and paper industrial

\section{PENDAHULUAN}

Struktur pasar merupakan suatu bahasan yang penting untuk mengetahui perilaku dan kinerja industri. Dalam struktur pasar terdapat tiga elemen pokok yaitu pangsa pasar (market share), konsentrasi (concentration), dan hambatan (barriers of entry). Pangsa pasar merupakan tujuan perusahaan, peranannya adalah sebagai sumber keuntungan bagi perusahaan. Sedangkan konsentrasi merupakan kombinasi pangsa pasar dari perusahaan-perusahaan oligopolis dimana terdapat adanya saling ketergantungan diantara perusahaan-perusahaan tersebut. Kombinasi pangsa pasar perusahaan-perusa- haan tersebut membentuk suatu tingkat konsentrasi dalam pasar (Wihana Kirana, 2001).

Industri pulp dan kertas merupakan industri dengan perkembangan yang baik, dilihat dari masih terbuka luas tingkat konsumsi kertas perkapita penduduk Indonesia yang terus meningkat dari $10 \mathrm{~kg}$ per kapita tahun 1992 menjadi 16,5 kg per kapita pada tahun 1997. krisis moneter pada pertengahan tahun 1997 sangat mempengaruhi konsumsi kertas masyarakat. Pada tahun 1998 tingkat konsumsi turun sampai dengan 13,8 kg per kapita. Hal ini disebabkan karena harga kertas sangat tinggi sehingga volume yang dikonsumsi masyarakat menurun dratis. Pada 
tahun 1999 konsumsi kertas mulai pulih pada angka $14,5 \mathrm{~kg}$ dan pada tahun 2000 tingkat konsumsinya dapat menyamai tingkat konsumsi sebelum krisis yaitu sebesar $16,5 \mathrm{~kg}$ per kapita. Pertumbuhan produksi kertas di Indonesia pada tahun 1996 mencapai 4.120.490 ton dan tahun 2000 produksi meningkat tajam menjadi 6.849 .000 ton. (Arif Ramelan dan Tri Mulyaningsih, 2001).

Struktur industri pulp dan kertas sangat kuat dibandingkan dengan industri lainnya yang ada di Indonesia. Industri ini tidak mengalami ketergantungan impor bahan baku, bahkan bahan baku dalam bentuk Akasia dan Eucalyptus tersedia dalam jumlah yang banyak untuk jangka waktu yang panjang. Dengan demikian membuat sektor industri ini memiliki keunggulan komparatif, dibandingkan industri dari negara pesaing seperti Amerika Serikat (AS) maupun Eropa. Di AS atau Eropa untuk mengadakan bahan baku produksi pulp dan kertas membutuhkan waktu 40 sampai 80 tahun, sedangkan di Indonesia hanya membutuhkan waktu enam tahun. Kekuatan inilah yang membuat penetrasi pasar industri kertas Indonesia ke pasar ekspor. Sektor industri pulp dan kertas menyumbang $50 \%$ dari total penerimaan ekspor sektor kehutanan. Sampai dengan tahun 2006 posisi industri pulp Indonesia menduduki peringkat kesembilan di dunia, dengan menguasai 2,4 persen pangsa pasar. Sementara industri kertas indonesia menduduki peringkat ke-12 dengan pangsa pasar 2,2 persen dari total produksi kertas dunia (Kompas, 2006).

Berdasarkan laporan Badan Pusat Statistik (BPS), tahun 1998 perekonomian Indonesia mengalami pertumbuhan $-13,68 \%$. Padahal tahun-tahun sebelumnya pertumbuhan selalu positif, yakni 4,91\% pada tahun
1997, tahun 1996 sebesar 7,82\%, tahun 1995 sebesar 8,22\% dan 7,54\% pada tahun 1994 . Krisis ekonomi yang berawal pada pertengahan tahun 1997 ikut memberikan dampak terhadap industri manufaktur di Indonesia, termasuk juga industri kertas dan pulp. Dalam kondisi krisis perusahaan-perusahaan hanya mempunyai dua pilihan. Pertama, mengurangi jumlah impor faktor produksi yang berarti harus mengurangi jumlah produksi. Pilihan kedua, jumlah faktor produksi yang diimpor tetap namun biaya yang dikeluarkan meningkat. Untuk mempertahankan keuntungannya, perusahaan harus menjual harga produknya dengan harga yang lebih tinggi.

Penelitian Ditya Agung (2002), rata-rata untuk seluruh industri manufaktur 17 subgolongan industri yang tercakup pada periode penelitian, telah terjadi peningkatan konsentrasi. Tingkat konsentrasi terjadi peningkatan, baik itu dengan CR4 maupun Indeks Herfindahl. Hasil riset publikasi Asian Pulp and Markets disebutkan bahwa Indonesia meraih performa ekonomi yang kuat pada tahun 1980 hingga 1990. Ini ditandai dengan pertumbuhan GDP berkisar 7,3 persen per tahun dari tahun 1990-an. Tahun 1994 terjadi regulasi dalam industri kertas dengan kebijakan menghilangkan tarif ekstra (surcharge) terhadap kertas impor, dimana kebijakan tarif ekstra (surcharge) tersebut menyebabkan harga kertas domestik lebih tinggi dibandingkan dengan harga internasional. Kebijakan ini dilakukan untuk lebih meningkatkan efisiensi industri kertas secara keseluruhan.

Perkembangan industri pulp dan kertas mengalami kegoncangan akibat krisis ekonomi tahun 1997 dan ini berlangsung hingga tahun 1999. Kondisi yang semakin membaik 
untuk industri pulp dan kertas terjadi pada tahun 2001 yang ditandai mulai terlihat adanya perubahan dari segi keuangan pada industri bersangkutan. Hampir seluruh perusahaan yang bergerak pada industri kertas pun mulai beranjak dari keterpurukannya.

\section{TINJAUAN PUSTAKA}

\section{Hubungan Struktur dan Kinerja}

Terdapat dua pendekatan yang saling bertentangan dalam menganalisis hubungan antara struktur pasar dan kinerja. Pendekatan yang pertama adalah: paradigma SCP (Structure Conduct Performance), dalam pendekatan ini lebih memfokuskan perhatiannya pada kolusi pasar. Sedang pendekatan yang kedua adalah hipotesis efisiensi yang menekankan pada efisiensi operasional yang tinggi. Interpretasi tradisional dari paradigma SCP didasarkan pada opini bahwa konsentrasi mendorong kolusi di antara perusahaan dalam industri. Menurut hipotesis ini, tingkat konsentrasi pasar mengakibatkan pengaruh langsung yang besar terhadap tingkat kompetisi dalam indusri. Hipotesis ini akan tampak nyata jika pengaruh dari konsentrasi pasar ditemukan positif signifikan, terlepas dari efisien tidaknya suatu perusahaan. Dengan demikian, semakin banyak perusahaan yang terkonsentrasi akan menghasilkan keuntungan (profit) yang tinggi (karena alasan kolusi atau monopoli) dibandingkan dengan perusahaan yang tidak atau kurang terkonsentrasi, berapapun efisiensinya. Ada beberapa studi empiris tentang SCP dalam industri dan sebagian besar hasil survei menunjukkan hasil yang mendukung hipotesis tradisional ini.

Namun demikian, studi-studi empiris awal SCP, di antaranya oleh Heggestad dan
Mingo (1977), Rhoades (1982), dan Spellman (1981) telah dikritik oleh Gilbert (1984), Osborne dan Wendel (1983) dalam Mudrajat kuncoro (2003), karena terdapat begitu banyak inkonsistensi dan kontradiksi serta meluasnya ketidakpuasan yang semakin kuat dari pendekatan tradisional. Sehingga hipotesis efisiensi muncul untuk menentang interpretasi tradisional dari hubungan SCP. Penjelasan hubungan antara struktur pasar dan kinerja dari perusahaan menurut hipotesis efisiensi, tergantung dari apakah perusahaan yang bersangkutan efisien atau tidak. Jika memang perusahaan mencapai tingkat efisiensi yang tinggi dibandingkan dengan pesaingnya (oleh karena struktur biaya yang relatif rendah), maka perusahaan dapat mengambil satu dari dua strategi sebagai berikut: (1) perusahaan yang efisien akan memaksimalkan keuntungan dengan mempertahankan harga dan ukuran perusahaan seperti yang terjadi selama ini, atau (2) perusahaan yang paling efisien akan memperoleh peningkatan pangsa pasar dan efisiensi akan menjadi driving force di belakang proses konsentrasi pasar. Studi empiris dari hipotesis efisiensi ini telah menjelaskan efisiensi tertentu dengan menggunakan variabel pangsa pasar. Hipotesis ini dibenarkan jika memang kinerja perusahaan tergantung dari pangsa pasarnya tanpa memperhitungkan tingkat konsentrasi pasar. Dalam dukungannya terhadap pendekatan efisinesi, Brozen (1982), Evanoff dan Fortier (1988), dan Smirlock (1985) menemukan efisien menjadi variabel dominan dalam menjelaskan profitabilitas industri. (Mudrajad Kuncoro, 2003)

Menurut penelitian Aswicahyono (2001) dalam Ditya Agung (2002), yang menguji relevansi antara pandangan SCP dan hipo- 
tesis efisiensi untuk kasus di Indonesia, ada perbedaan-perbedaan yang sangat mendasar antara kedua pandangan tersebut. Pandangan pertama, tentang SCP, melihat bahwa kekuasaan pasar dapat digunakan untuk mengurangi kompetisi dengan tujuan mengeksploitasi konsumen dengan harga yang tinggi dari average cost yang terendah yang mengakibatkan adanya welfare loss. Teori SCP juga menyimpulkan bahwa tingginya konsentrasi pasar mempermudah perusahaan untuk menggunakan kekuasaan pasarnya dengan menghasilkan keuntungan yang tinggi. Hal ini sebagai tanda kinerja pasar yang rendah karena konsumen membayar harga yang lebih tinggi.

Pendapat kedua, yang dikenal dengan istilah chicago school yang didasari oleh penelitian Demsetz (1973) (dalam Ditya Agung, 2002), memberikan interpretasi yang berbeda mengenai hubungan antara keuntungan, kinerja dan konsentrasi. Tingginya tingkat keuntungan tidak selalu menunjukkan kinerja yang rendah. Menurut pandangan ini, sebuah perusahaan yang efisien atau inovatif dapat menarik konsumen dengan memberikan harga yang lebih rendah atau barang dengan kualitas yang lebih baik sehingga perusahaan tersebut mendapatkan tingkat keuntungan yang lebih tinggi dan kekuasaan pasar yang lebih besar. Martin (1998) melakukan penelitian untuk industri di Amerika guna menguji kedua hipotesis di atas. Hipotesis market power akan terbukti jika price cost margin untuk perusahaan kecil hampir sama dengan perusahaan besar. Hal ini dikarenakan samanya profit rate menandakan adanya kolusi harga antara perusahaan besar yang akan juga menguntungkan perusahaan kecil. Di lain pihak, hipotesa efficiency-profitability akan terbukti jika profit rate untuk perusahaan menurun dengan mengecilnya market share perusahaan. Hal ini dikarenakan perusahaan besar dapat menikmati skala ekonomi yang lebih besar dan adanya keunggulan yang inherent dengan semakin besarnya sebuah perusahaan.

\section{Hipotesis}

1. Diduga konsentrasi perusahaan pulp dan kertas yang diukur dengan $\mathrm{CR}_{4}$ dan $\mathrm{CR}_{8}$ setelah krisis (2001) lebih tinggi daripada konsentrasi perusahaan sebelum krisis (1994).

2. Struktur industri kertas dan pulp berpengaruh terhadap kinerja perusahaan (yang ditunjukkan oleh nilai tambah) dengan perincian sebagai berikut:

a. Diduga bahan baku berpengaruh negatif terhadap nilai tambah perusahaan

b. Diduga biaya modal berpengaruh negatif terhadap nilai tambah perusahaan

c. Diduga pangsa pasar perusahaan berpengaruh positif terhadap nilai tambah perusahaan.

\section{METODE PENELITIAN}

\section{Definisi Operasional Variabel}

Berikut ini diberikan batasan pengertian dari variabel-variabel yang digunakan dalam penelitian, antara lain:

\section{a. Nilai Tambah (NT)}

Nilai Tambah merupakan keuntungan industri yang mencerminkan kelebihan output terhadap input. Nilai Tambah dihitung sebagai nilai barang yang diproduksi atau output dikurangi penjumlahan biaya input dalam tahun t. Nilai Tambah dalam penelitian ini digunakan sebagai 
proxy kinerja industri pulp dan kertas. (ribu rupiah)

b. Biaya Modal Perusahaan $=\mathrm{BM}$

Variabel ini adalah penjumlahan dari biaya sewa tanah dan gedung ditambah dengan beban bunga yang dikeluarkan oleh perusahaan dalam tahun t. (ribu rupiah)

c. Bahan baku $=$ BBtot

Dihitung total bahan baku yang digunakan oleh perusahaan yang merupakan penjumlahan dari bahan baku domestik ditambah dengan bahan baku impor. dalam tahun t. (ribu rupiah)

d. Pangsa Pasar/Market Share (MS)

Merupakan pengukuran konsentrasi masing-masing perusahaan berdasarkan output perusahaan pada tahun t. Kombinasi pangsa pasar perusahaan-perusahaan tersebut membentuk suatu tingkat konsentrasi dalam pasar. (persen)

e. Efisiensi

Variabel effisiensi diukur dengan cara membandingkan output dibagi dengan input (persen).

\section{Jenis dan Sumber Data}

Berdasarkan sumbernya, data yang digunakan dalam penelitian ini adalah data sekunder. Data industri kertas dan pulp yang dipergunakan dalam penelitian ini adalah data industri dengan spesifikasi ISIC 5 digit yang diperoleh dari statistik industri manufaktur sedang dan besar di Indonesia (BPS), sedangkan data-data pendukung lain diperoleh dari studi literatur dan instansi terkait. Dilihat dari bentuk dan rentang waktunya, maka data yang dibutuhkan dan digunakan untuk estimasi parameter yang diamati dalam analisis ini adalah data industri (crosssection) tahun 1994 dan tahun 2001 yaitu data industri kertas dan pulp tahun 1994 dan data tahun 2001 .

\section{Teknik Analisis}

\section{Analisis deskriptif}

Dalam analisis industri, menurut Hasibuan (1993), ada beberapa cara mengamati kaitan antara struktur, perilaku dan kinerja. Pertama, hanya memperhatikan secara mendalam dua aspek, yaitu kaitan antara struktur dan kinerja industri, sedangkan aspek perilaku kurang ditekankan. Kedua, pengamatan kinerja dan perilaku, dan kemudian dikaitkan lagi dengan struktur. Ketiga, menelaah kaitan struktur terhadap perilaku dan kemudian diamati kinerjanya. Keempat, kinerja tidak perlu diamati lagi, oleh karena telah dijawab dari hubungan struktur dan perilakunya.

Dalam penelitian ini akan digunakan cara yang pertama. Dengan kata lain lebih menekankan aspek struktur dan kinerja industri kertas dan pulp. Sedangkan pertanyaan penting dalam penelitian tentang apakah krisis ekonomi mengubah struktur industri adalah dengan menggunakan metode rasio konsentrasi. Metode rasio konsentrasi yang digunakan dalam penelitian ini adalah CR-4 (concentration ratio-4) dan CR-8 (concentration ratio-8). Dalam metode ini menurut Church and Ware, 2000; Clarke, 1994; Hasibuan 1993 adalah: 
a. Rasio Konsentrasi (concentration ratio-4).

$$
\mathrm{CR}_{4}=\frac{\text { Jumlah } 4 \text { Perusahaan Terbesar yang Diamati }}{\text { Jumlah Seluruh Sektor Industri yang Diamati Tersebut }} \times 100 \%
$$

b. Rasio Konsentrasi (concentration ratio-8).

$$
\mathrm{CR}_{8}=\frac{\text { Jumlah } 8 \text { Perusahaan Terbesar yang Diamati }}{\text { Jumlah Seluruh Sektor Industri yang Diamati Tersebut }} \times 100 \%
$$

Dengan membandingkan hasil pengukuran rasio konsentrasi tersebut di atas dengan kriteria/klasifikasi struktur pasar, maka bentuk struktur pasar dapat ditentukan. Menurut JB. Bain (1958) pengukuran konsentrasi tidak hanya terbatas pada jumlah barang yang ditawarkan saja, tetapi bisa juga diukur melalui nilai tambah yang diciptakan, jumlah tenaga kerja yang digunakan atau biaya tenaga kerja, nilai tambah yang dihasilkan perusahaan. Dalam penelitian ini Pengukuran konsentrasi tersebut akan dibandingkan antara tahun prakrisis (1994) dan tahun pascakrisis (2001) dan akan digunakan pengukuran dengan $\mathrm{CR}_{4}$ dan pengukuran konsentrasi dengan $\mathrm{CR}_{8}$.

Menurut Nurimansjah Hasibuan klasifikasi tersebut dapat ditentukan. Klasifikasi tersebut nampak dalam tabel 1 .

\section{Tabel 1. Tipe-tipe Struktur Pasar Oligopoli}

\begin{tabular}{ccl}
\hline No. & CR (\%) & Tipe Struktur Pasar \\
\hline 1. & $>85$ & Oligopoli Konsentrasi Tinggi \\
2. & $84-70$ & Oligopoli Konsentrasi Sedang \\
3. & $69-45$ & Oligopoli Konsentrasi Rendah \\
4. & $44-30$ & Oligopoli Rendah \\
5. & $<30$ & Poli-poli/Atomistik \\
\hline
\end{tabular}

Sumber: Nurimansjah Hasibuan, 1994
Struktur poli-poli masih dapat dibagi dalam beberapa kategori, yaitu:

a. Rasio konsentrasi antara 17\%-29\%: polipoli konsentrasi tinggi

b. Rasio konsentrasi antara 4\%-16\%: polipoli konsentrasi sedang

c. Rasio konsentrasi kurang dari 3\%: polipoli konsentrasi rendah

\section{Estimasi Ordinary Least Square (OLS) dan Asumsi Klasik}

Untuk analisis hubungan antara konsentrasi industri, struktur pasar dan kinerja industri akan diamati dengan model persamaan industri kertas dan pulp. Model ekonometrika ini diambil dari literatur standar ekonomi industri yang menjelaskan hubungan struktur, perilaku, dan kinerja perusahaan/ industri. Dan dari model yang digunakan Geroski.et.al (1987) yang sudah dimodifikasi, Bentuk fungsi regresinya adalah

$\mathrm{NT}=f\left(\mathrm{BE}_{\mathrm{i}}, \mathrm{CR}_{\mathrm{i}}, \ldots\right)$

dimana $\mathrm{i}$ adalah jenis industri, $\pi_{\mathrm{i}}$ sebagai pengukuran tingkat keuntungan industri, $\mathrm{BE}_{\mathrm{i}}$ adalah hambatan masuk, $\mathrm{CR}_{\mathrm{i}}$ adalah rasio konsentrasi, dan variabel-variabel lain yang dapat mempengaruhi perolehan keuntungan. Model akan diuji dengan metode Ordinary Least square untuk menentukan nilai-nilai taksiran dari parameter-parameter yang 
meminimumkan jumlah kuadrat residu (Gunawan Sumodiningrat, 1998). Dengan bentuk fungsi sebagai berikut:

- Regresi Tahun 1994

$$
\begin{aligned}
\mathrm{NT}= & \mathrm{ao}+\mathrm{aMS}+\mathrm{a} 2 \mathrm{BM}_{\mathrm{i}}+\mathrm{a} 3 \mathrm{EFI}_{\mathrm{i}}+ \\
& \mathrm{a} 4 \mathrm{BBtot}_{\mathrm{i}}+\mathrm{el}
\end{aligned}
$$

- Regresi tahun 2001

$$
\begin{aligned}
\mathrm{NT}= & \mathrm{ao}+\mathrm{aMS}+\mathrm{a} 2 \mathrm{BM}_{\mathrm{i}}+\mathrm{a}_{3 \mathrm{EFI}_{\mathrm{i}}+} \\
& \mathrm{a} 4 \mathrm{BBtot}_{\mathrm{i}}+\mathrm{el}
\end{aligned}
$$

a. Uji Signifikansi Parameter Individual (Uji Statistik t)

Uji statistik t pada dasarnya menunjukkan seberapa jauh pengaruh masingmasing variabel penjelas/independen secara individual dalam menerangkan variasi variabel dependen. Uji statistik $t$ untuk variabel bahan baku dan biaya modal menggunakan hipotesis Ho : $b_{i}=$ 0 dan $\mathrm{Ha}: \mathrm{b}_{1}<0$. Jika $t$ hitung lebih kecil dari $\mathrm{t}$ tabel pada tingkat kepercayaan 95\% (atau p-value < 0,05) maka Ho ditolak dan Ha diterima, artinya variabel independen yang diuji mempunyai pengaruh negatif terhadap variabel dependen. Uji statistik $t$ untuk variabel efisiensi dan pangsa pasar menggunakan hipotesis Ho $: b_{i}=0$ dan Ha $: b_{1}>0$. Jika $\mathrm{t}$ hitung lebih besar dari $\mathrm{t}$ tabel pada tingkat kepercayaan 95\% (atau p-value < 0,05) maka Ho ditolak dan Ha diterima, artinya variabel independen yang diuji mempunyai pengaruh positif terhadap variabel dependen.

b. Uji Signifikansi Simultan (Uji Statistik F)
Uji statistik $\mathrm{F}$ pada dasarnya menunjukkan apakah semua variabel babas yang dimasukkan dalam model mempunyai pengaruh secara bersama-sama terhadap variabel terikat/dependen. Pengujian $\mathrm{F}$ dilakukan dengan hipotesis $\mathrm{H}_{\mathrm{o}}: \mathrm{b}_{1}=\mathrm{b}_{2}$ $=\ldots \ldots \ldots . .=b_{k}=0$ artinya terdapat pengaruh nyata dari variabel bebas secara bersama-sama terhadap variabel terikat. Pengujian dilakukan dengan membandingkan $\mathrm{F}$ hitung dengan $\mathrm{F}$ tabel. Jika $\mathrm{F}$ hitung lebih besar dari $\mathrm{F}$ tabel dengan tingkat kepercayaan 95\% (atau p-value < $0,05)$, maka Ha diterima, artinya variabel independen yang diuji secara bersamasama mempunyai pengaruh terhadap variabel dependen.

\section{c. Uji Koefisien Determinasi}

Koefisien determinasi $\left(\mathrm{R}^{2}\right)$ pada intinya mengukur seberapa jauh kemampuan model dalam menerangkan variasi dependen. Nilai koefisien determinasi adalah di antara nol dan satu. Nilai $\mathrm{R}^{2}$ yang kecil berarti kemampuan variabel-variabel independen menjelaskan variasi variabel dependen amat terbatas. Nilai yang mendekati satu berarti variabel-variabel independen memberikan hampir semua informasi yang dibutuhkan untuk memprediksi variasi variabel dependen.

d. Uji Asumsi Klasik

Dalam uji asumsi klasik yang akan digunakan dalam penelitian ini adalah uji multikolonieritas dan uji heteroskedastisitas. Uji multikolinieritas bertujuan untuk menguji apakah model regresi ditemukan adanya korelasi antar variabel bebas (independen). Model regresi yang baik seharusnya tidak terjadi korelasi antar variabel bebas. Jika variabel bebas 
saling korelasi, maka variabel ini tidak ortogonal. (Gujarati, 2003). Untuk melihat apakah di dalam model terdapat multikolinieritas atau tidak maka dilakukan pengujian multikolinieritas dengan Klein's Rule of Tumb ini dilakukan dengan melihat nilai $\mathrm{R}^{2}$ setiap auxiliary regression dan harus lebih kecil dari $\mathrm{R}^{2}$ utama. Serta secara langsung bisa dilihat nilai $\mathrm{R}^{2}$ nya, jika nilai $\mathrm{R}^{2}$ sangat tinggi namun nilai $\mathrm{t}$ banyak yang tidak signifikan berarti dalam model terdapat multikolinieritas. Untuk memperbaiki multikolinieritas maka dilakukan dengan cara membuang variabel yang tidak signifikan.

Uji Heteroskedastisitas bertujuan menguji apakah dalam model regresi terjadi ketidaksamaan variance dan residual satu pengamatan ke pengamatan yang lain. Jika variance dari residual satu pengamatan ke pengamatan yang lain tetap, maka disebut Homoskedastisitas dan jika berbeda disebut Heteroskedastisitas (Gujarati, 2003). Untuk melakukan pengujian terhadap model apakah terdapat Heteroskedastisitas adalah dengan Park Test. Langkah pengujian dengan Park Test adalah dengan cara menguadratkan nilai residual e12 menjadi e1^2 dan meregres semua logaritma natural dari variabel e12 (variabel dependen) dengan logaritma natural semua variabel independen yang terdapat pada persamaan mula-mula. Kemudian dilihat nilai $\mathrm{t}$ hitung, apabila koefisien parameter $\beta$ dari persamaaan regresi tersebut signifikan secara statistik, hal itu menunjukkan bahwa dalam data model empiris yang diestimasi terdapat Heteroskedastisitas, dan sebaliknya jika koefisien parameter $\beta$ dari persamaaan regresi tersebut tidak signifikan secara statistik, hal itu menunjukkan bahwa asumsi Homoskedastisitas pada data model tersebut tidak dapat ditolak. Sedangkan metode perbaikan heteroskedastisitas dilakukan dengan melakukan transformasi log atas model regresi asal sehingga diperoleh:

$$
\begin{aligned}
& \log (\mathrm{Y})=\beta \mathrm{o}+\beta_{1} \log (\mathrm{MS})+ \\
& \beta_{2} \log (\mathrm{BM})+\beta_{3} \log (\text { BBtot })+\mathrm{v}
\end{aligned}
$$

\section{HASIL DAN PEMBAHASAN}

\section{Deskriptif Tingkat Konsentrasi Indus-} tri Pulp dan Kertas Tahun 1994 dan Tahun 2001

Industri pulp dan kertas tingkat konsentrasinya berdasarkan $\mathrm{CR}_{4}$ dan $\mathrm{CR}_{8}$ dapat dilihat pada tabel 2 .

Tabel 2. Tingkat Konsentrasi Industri Pulp dan Kertas

\begin{tabular}{lll}
\hline \multicolumn{1}{r}{ Keterangan } & $\mathbf{1 9 9 4}$ & $\mathbf{2 0 0 1}$ \\
\hline CR $_{\mathbf{4}}$ & & \\
CR Bahan Baku & $50 \%$ & $68 \%$ \\
CR Output & $54 \%$ & $57 \%$ \\
CR Upah & $53 \%$ & $40 \%$ \\
CR Nilai Tambah & $65 \%$ & $68 \%$ \\
CR & & \\
CR Bahan Baku & & \\
CR Output & $67 \%$ & $82 \%$ \\
CR Upah & $70 \%$ & $79 \%$ \\
CR Nilai Tambah & $67 \%$ & $55 \%$ \\
\hline
\end{tabular}

Sumber: diolah dari data primer

Dengan jumlah perusahaan sebanyak 135 perusahaan pada tahun 1994 dan sebanyak 156 perusahaan pada tahun 2001, dapat disimpulkan bahwa menurut Hasibuan 
(1993) maka tingkat konsentrasi industri pada industri pulp dan kertas untuk $\mathrm{CR}_{4}$ adalah Oligopoli Konsentrasi rendah, dimana industri dengan tingkat konsentrasi antara 45\%-69\% dikatakan tipe oligopoli konsentrasi rendah. Sedangkan tingkat konsentrasi industri pulp dan kertas untuk $\mathrm{CR}_{8}$ rata-rata adalah Oligopoli Konsentrasi sedang, yaitu tingkat konsentrasi antara 70\%-84\%.

Tingkat konsentrasi bahan baku total, output, dan nilai tambah meningkat baik dilihat dari $\mathrm{CR}_{4}$ maupun dilihat dari $\mathrm{CR}_{8}$. Sedangkan untuk konsentrasi biaya upah menurun baik dilihat dari $\mathrm{CR}_{4}$ maupun dilihat dari $\mathrm{CR}_{8}$. Penurunan konsentrasi tingkat upah karena industri pulp dan kertas merupakan industri padat modal sehingga dimungkinkan bahwa industri pulp dan kertas yang semakin besar akan menggunakan tehnologi yang semakin canggih. Penggunaan tehnologi canggih akan diimbangi dengan pengurangan jumlah tenaga kerja dan ini akan mengakibatkan efisiensi pada tingkat upah atau biaya upah yang semakin rendah.

\section{Analisis Regresi}

Penelitian ini akan melihat bagaimana pengaruh variabel bebas terhadap variabel terikatnya. Di samping juga untuk mengetahui mana diantara model-model tersebut yang lebih baik dalam menjelaskan variasi nilai tambah dengan cara melihat nilai $\beta$ pada masing-masing model. Pada tahun 1994 tidak terdapat masalah multikolinieritas, sedangkan pada tahun 2001 terdapat masalah multikolinieritas. Untuk tahun 1994 terdapat masalah heteroskedastisitas dan tahun 2001 tidak terdapat masalah heteroskedastisitas. Dari dua model ini kita ingin melihat bagaimana kondisi sebelum dan pasca krisis industri pulp dan kertas maka harus menggunakan variabel yang sama, karena tahun 2001 terdapat multikolinieritas maka variabel efisiensi dihilangkan dalam model. Untuk interpretasi hasil yang sama maka tahun 1994 variabel efisiensi juga dihilangkan dalam model. Sehingga persamaan dalam model menjadi:

$\mathrm{NT}=\mathrm{ao}+\mathrm{aMS}+\mathrm{a} 2 \mathrm{BM}_{\mathrm{i}}+\mathrm{a} 4 \mathrm{BBtot}_{\mathrm{i}}+\mathrm{el}$

a. Interpretasi Koefisien Tahun 1994

Dalam analisis regresi tahun 1994 terlihat bahwa model yang digunakan dapat menjelaskan variasi nilai tambah. Ini dapat dilihat dari nilai probabilitas Fstatistiknya yang signifikan pada level 1\%. Signifikansinya nilai F-statistik kan bahwa secara bersama-sama variabel

Tabel 3. Hasil Regresi Data Tahun 1994 Setelah Uji Asumsi Klasik

\begin{tabular}{lcrrl}
\hline \multicolumn{1}{c}{ Variabel } & Tanda diharapkan & Coefficient & t-statistik & Prob \\
\hline C & & 33.00905 & 11.68237 & 0.0000 \\
Bahan Baku & Negatif & -0.590531 & -5.154637 & 0.0000 \\
CROutput/MS & Positif & 1.526654 & 10.584990 & 0.0000 \\
Biaya Modal & Negatif & -0.006813 & -0.105511 & 0.9164 \\
\hline F-statistik & & 415.1496 & & 0.000000 \\
R-squared & & 0.963 & & \\
Adjusted R-square & & 0.961 & & \\
\hline
\end{tabular}

Sumber: diolah dari data primer 
independen dapat mempengaruhi secara signifikan terhadap variabel dependen. Sehingga dari model tersebut baik biaya modal, biaya bahan baku maupun pangsa pasar secara bersama-sama dapat menjelaskan nilai tambah. Jika dilihat dari pengaruh masing-masing variabel independen terhadap variabel dependen maka variabel bahan baku dan pangsa pasar mempunyai pengaruh signifikan pada level $1 \%$. Sedangkan untuk variabel biaya modal mempunyai pengaruh yang tidak signifikan baik pada level $1 \%, 5 \%$, maupun $10 \%$.

Bahan baku mempunyai koefisien $-0,590531$ yang berarti bahwa penurunan bahan baku sebesar Rp.1 ribu akan meningkatkan nilai tambah perusahaan sebesar Rp. 0,590531 ribu. Semakin kecil bahan baku yang digunakan perusahaan akan berpengaruh semakin meningkatkan nilai tambah. Variabel biaya modal mempunyai nilai koefisien yakni $-0,006813$ yang berarti bahwa penurunan biaya modal perusahaan sebesar Rp.1 ribu akan meningkatkan nilai tambah perusahaan besar nilai tambah yang dihasilkan perusahaan. Sedangkan untuk variabel pangsa pasar memiliki tanda positif. Berarti peningkatan pangsa pasar perusahaan sebesar 1 persen akan meningkatkan nilai tambah perusahaan sebesar 1,526654 persen. Semakin besar pangsa pasar dikuasai perusahaan akan semakin besar nilai tambah yang dihasilkan.

b. Interpretasi Koefisien Tahun 2001

Dalam analisis regresi tahun 2001 terlihat bahwa model yang digunakan dapat menjelaskan variasi nilai tambah. Ini dapat dilihat dari nilai probabilitas Fstatistiknya yang signifikan pada level 1\%. Signifikansinya nilai F-statistik menunjukkan bahwa secara bersama-sama variabel independen dapat mempengaruhi secara signifikan terhadap variabel dependen. Sehingga dari model tersebut baik biaya modal, bahan baku maupun pangsa pasar secara bersama-sama dapat menjelaskan nilai tambah. Jika dilihat dari pengaruh masing-masing variabel independen terhadap variabel dependen maka variabel biaya modal, bahan baku dan

Tabel 4. Hasil Regresi Data Tahun 2001 Setelah Uji Asumsi Klasik

\begin{tabular}{lcrrr}
\hline \multicolumn{1}{c}{ Variabel } & Tanda diharapkan & Coefficient & t-statistik & \multicolumn{1}{c}{ Prob } \\
\hline C & & 4451207. & 2.959289 & 0.0036 \\
Bahan Baku & Negatif & -0.379631 & -14.49876 & 0.0000 \\
CROutput/MS & Positif & $1.76 \mathrm{E}+10$ & 19.66536 & 0.0000 \\
Biaya Modal & Negatif & -0.175843 & -4.783205 & 0.0000 \\
\hline F-statistik & & 2258.124 & & 0.000000 \\
R-squared & & 0.978 & \\
Adjusted R-square & & 0.977 & \\
\hline
\end{tabular}

Sumber: diolah dari data primer

sebesar Rp. 0,544842 ribu. Semakin kecil

penggunaan biaya modal akan semakin 
pangsa pasar mempunyai pengaruh signifikan pada level $1 \%$.

Bahan baku mempunyai koefisien $-0,379631$ yang berarti bahwa penurunan penggunaan bahan baku sebesar Rp.1 ribu akan meningkatkan nilai tambah perusahaan sebesar Rp. 0,379631 ribu. Semakin kecil bahan baku yang digunakan perusahaan akan berpengaruh semakin meningkatkan nilai tambah. Variabel biaya modal mempunyai nilai koefisien yakni $-0,175843$ yang berarti bahwa penurunan biaya modal perusahaan sebesar Rp.1 ribu akan meningkatkan nilai tambah perusahaan sebesar Rp. 0,175843 ribu. Semakin kecil penggunaan biaya modal akan semakin besar nilai tambah yang dihasilkan perusahaan. Sedangkan untuk variabel CR output/pangsa pasar memiliki tanda positif. Yang berarti bahwa peningkatan pangsa pasar perusahaan sebesar 1 persen akan meningkatkan nilai tambah perusahaan sebesar 1,76 persen. Semakin besar pangsa pasar dikuasai perusahaan akan semakin besar nilai tambah yang dihasilkan.

\section{KESIMPULAN}

Dari perhitungan rasio konsentrasi dan perhitungan regresi yang telah dilakukan, ada beberapa hal penting yang dapat disimpulkan yaitu:

1. Nilai rasio konsentrasi dari $\mathrm{CR}$ bahan baku, CR nilai tambah dan CR output semuanya meningkat baik untuk $\mathrm{CR}_{4}$ maupun untuk $\mathrm{CR}_{8}$. Ini berarti bahwa krisis telah menyebabkan peningkatan rasio konsentrasi industri kertas dan pulp. Dengan adanya krisis ekonomi telah menyebabkan banyak perusahaan yang tutup. Perusahaan yang tidak mampu bertahan mempunyai pangsa pasar yang kecil, dengan keluarnya mereka dari industri, pasarnya akan diambil alih oleh perusahaan lain yang pangsa pasarnya lebih besar. Sehingga tingkat konsentrasi pada industri yang bersangkutan meningkat.

2. CR yang mengalami penurunan adalah $\mathrm{CR}$ upah. Untuk $\mathrm{CR}_{4}$ menurun sebesar $13 \%$ dan untuk $\mathrm{CR}_{8}$ menurun sebesar 12\%. Meskipun dilihat dari nilai $\mathrm{CR}$ upah menurun namun jika dilihat dari kenaikan tingkat upah empat perusahaan terbesar dan delapan perusahaan terbesar mengalami kenaikan yang cukup besar yakni 3 kali untuk $\mathrm{CR}_{4}$ dan 4 kali untuk $\mathrm{CR}_{8}$. Penurunan $\mathrm{CR}$ upah disebabkan karena industri ini merupakan industri padat modal dengan penggunakan teknologi tinggi.

3. Pembentukan $\mathrm{CR}_{4}$ dan $\mathrm{CR}_{8}$ untuk biaya upah, biaya bahan baku total, nilai tambah dan output, dihasilkan oleh perusahaan yang tidak sama karena adanya hubungan antara biaya input (upah dan bahan baku), output, dan nilai tambah. Nilai tambah perusahaan selain dipengaruhi output yang dihasilkan juga dipengaruhi biaya input. Output yang tinggi jika diikuti biaya input yang tinggi akan menghasilkan nilai tambah yang rendah dan sebaliknya. Pembentukan tingkat konsentrasi dapat dilakukan berdasarkan nilai tambah, upah atau output perusahaan tanpa melihat perusahaan yang membentuk nilai konsentrasi. Menurut Kilpatrik, 1967, seorang peneliti dapat menggunakan konsentrasi secara umum (ordinary concentration rasio) untuk penelitian cross section tanpa 
khawatir bahwa pilihan yang dipakai akan mempengaruhi kesimpulan yang diperoleh.

4. Nilai rasio konsentrasi untuk $\mathrm{CR}_{4}$ maupun untuk $\mathrm{CR}_{8}$ dari $\mathrm{CR}$ bahan baku, $\mathrm{CR}$ nilai tambah, $\mathrm{CR}$ output maupun $\mathrm{CR}$ upah, nilai rasio konsentrasi dilihat dari masing-masing perusahaan bukan kelompok perusahaan, sehingga dimungkinkan bahwa tingkat konsentrasi yang sebenarnya lebih tinggi.

5. Dalam analisis cross-section model regresi tahun 1994 dengan variabel dependen nilai tambah dan variabel independennya adalah biaya modal, biaya bahan baku dan pangsa pasar ternyata mampu menjelaskan variasi nilai tambah. Hal ini ditunjukkan dengan nilai F-statistik yang signifikan. Demikian juga untuk model regresi tahun 2001 dengan variabel dependen nilai tambah dan variabel independennya adalah biaya modal, biaya bahan baku dan pangsa pasar ternyata mampu menjelaskan variasi nilai tambah. Hal ini ditunjukkan nilai F-statistik yang signifikan

6. Regresi tahun 1994 dengan variabel independen biaya bahan baku dan pangsa pasar dapat menjelaskan secara signifikan terhadap nilai tambah sedangkan variabel biaya modal tidak signifikan. Hal ini ditunjukkan dari nilai t-hitung yang signifikan pada level $1 \%$. Sedangkan variabel biaya modal mempunyai nilai t-hitung tidak signifikan. Sedangkan untuk tahun 2001 variabel independen biaya bahan baku, biaya modal dan pangsa pasar dapat menjelaskan secara signifikan terhadap nilai tambah. Hal ini ditunjukkan nilai t-hitung yang signifikan pada level $1 \%$
7. Hasil penelitian ini menunjukkan bahwa biaya modal berpengaruh negatif terhadap nilai tambah perusahaan. Perusahaan yang mempunyai biaya modal lebih kecil akan mempunyai nilai tambah yang lebih besar. Ada kecenderungan bahwa perusahaan besar lebih murah untuk mendapatkan biaya modal. Hal ini disebabkan perusahaan besar dapat memperoleh pinjaman modal dengan tingkat bunga lebih rendah daripada perusahaan baru potensial.

8. Variabel biaya bahan baku berpengaruh negatif terhadap nilai tambah perusahaan. Biaya bahan baku yang semakin besar akan mengurangi nilai tambah yang diperoleh perusahaan. Sehingga perusahaan yang memiliki kontrol atas bahan baku membuat perusahaan dapat menentukan harga yang lebih rendah dari perusahaan saingannya. Dalam pasar oligopoli ada indikasi penguasaan bahan baku oleh perusahaan besar. Implikasinya perusahaan-perusahaan kecil tidak dapat berproduksi dengan lancar karena mahalnya harga bahan baku.

9. Variabel Concentration Ratio Output/ pangsa pasar berpengaruh positif terhadap tingkat keuntungan perusahaan. Menurut Baim (1956) terdapat hubungan yang positif antara konsentrasi pasar/ pangsa pasar dengan tingkat keuntungan dengan hambatan masuk yang sedang. Untuk hambatan masuk yang cukup tinggi konsentrasi perusahaan akan menciptakan keuntungan ekstra bagi perusahaan. 


\section{DAFTAR PUSTAKA}

Arif Ramelan. K dan Tri Mulyaningsih. 2002. Integrasi Vertikal dan Efissiensi Industri: Industri Kertas Tahun 19791997 dengan Pendekatan Error Correcion Model, Jurnal Ekonomi dan Bisnis Indonesia. Vol. 17, No.2, 2002, hlm. 136-149.

Bain, Joe. S. 1951. Relation of Profil Rate to Industry Concertation. Quarterly Journal of Economics 65, hlm 293-324.

Bain, Joe. S. 1956. Industrial Organization. New York: John Wiley and Sons

Bain, Joe. S. 1959. Industrial Organization. New York: John Wiley and Sons.

Biro Pusat Statistik. 2001. Survey Tahunan Perusahaan Besar dan Sedang. Jakarta: BPS.

Collins, Norman R and Preston Lee. E. 1969. "Price-cost Margin and Industry Structure". Review Economics and Statistics 51, hlm 304-314

Ditya Agung Nurdianto. 2002. Analisis Kolusi Industri Manufaktur Indonesia. Journal Ekonomi, hlm 16-43.

Evanoff, D.D. and D.L. Fortier. 1988. "Reevaluation of Structure Conduct Performance Paradigm in Banking", Journal of Financial Services Research 1 (June)

Geroski. Paul, A. Robert, T. Masson and Joseph Shaanan 1987. "The Dinamics of Market Structure". International Journal of Industrial Organization. 5. No.1.

Gujarati, Damodar. 2003. Basic Econometric. Fourth Edition. McGraw-Hill Book.co.
Gunawan Sumodiningrat,1996, Ekonometrika Pengantar, Yogyakarta: BPFE UGM.

Krousse, Clemen G. 1990. Theory of Industrial Economics. USA: Basil Blackweel Inc.

Martin, Stephen. 1988. Market Power and/or Efficiency?, The Review of Economics and Statistics, Vol. 70, Issue 2, May, hlm. 331-335.

Martin, Stephen. 1994. Industrial Economics, Economic Analysis and Public Policy. New York: Macmillan Publishing Company.

Mudrajad Kuncoro dan Anggito Abimanyu. 1994. Struktur dan Kinerja Industri Indonesia dalam Era Deregulasi dan Globalisasi. Jurnal Kelola No. 10/VII/ 1994, hlm. 50-75.

Mudrajad Kuncoro. 2002. Perekonomian Indonesia Beberapa Isu Penting. Jakarta: Ghalia Indonesia.

Mudrajad Kuncoro. 2003. Metode Kuantitatif. Jakarta: Erlangga.

Mudrajad Kuncoro. 2003. Metode Riset untuk Bisnis \& Ekonomi (Bagaimana Meneliti \& Menulis Tesis?). Jakarta: Erlangga.

Nurimansjah Hasibuan dan Wan Usman, 1987. Ekonomi Industri. Jakarta: Karunika UT.

Nurimansjah Hasibuan. 1984. Pembagian Tingkat Penghasilan Tenaga Kerja pada Industri-industri Oligopolistik di Indonesia. Disertasi tidak Dipublikasikan.

Nurimansjah Hasibuan. 1993. Ekonomi Industri: Persaingan, Monopoli dan Regulasi. Jakarta: LP3ES. 
Nurimansjah Hasibuan. 1994. Ancaman Kerapuhan Struktur Industri Pengolahan di Indonesia. Jurnal Kelola No. 6/II/94, hlm. 76-94.

Nurimansjah Hasibuan. 1997. Demokrasi Ekonomi dalam Monopoli dan Distorsi, Jurnal Bisnis \& Ekonomi Politik. Vol. 1 (3), hlm. 15-31.

Osborn, D.K. and J. Wendel. 1983. Research in Structure, Conduct and Performance in Banking 1964-1979. Research paper 83-003. College of Business Administration, Oklahoma State University, Juli.

Pindick, Robert.S and Rubinfeld Daniel. L. 1991. Econometric Modals and Economic Forcasts. Singapore: McGraw-Hill Book Company.
Rhoades, S. 1982. "Welfare loss, Redistribution Effect, and Restriction of Output Due Monopoly", Journal of Monetery Economics 9, hlm. 375-384.

Shepherd, William.G. 1990. The Economics of Industrial Organization. New Jersey: Prentice Hall Inc.

Wahyu Ariani dan Sri Susilo. 2003. Kajian Industri Mobil: Pendekatan Struktur dan Perilaku. Jurnal Modus Vol. 15 (2), hlm 89-104.

Wihana Kirana Jaya. 2001. Ekonomi Indusri. Edisi Revisi. Jogjakarta: BPFE UGM.

Yayasan Bentara Rakyat. Harian Kompas No. 307, Tahun 41, 12 Mei 2006, hlm. 18, Kol. 1. 